\title{
Women Empowerment: A Case Study on Elected Women of Local Government in Lalmonirhat District of Bangladesh
}

\author{
ASM Monowarul Islam \\ Research Scholar, Department of Political Science, Raiganj University, West Bengal, India
}

Corresponding author: monowarul.principal@yahoo.com

Received: 04-08-2020

Revised: 27-08-2020

Accepted: 12-10-2020

\begin{abstract}
The main concern of this research was to find out the present scenario of women empowerment in local government institutions in Lalmonirhat district. For this purpose, 85 participants were selected purposively. A survey design used in this study. After analysis the collected data it was shown women members of Zila Parishad mean score is $(M=134.40)$ which is more than the other institutions. Mean difference of five Upazila where empowered women live Patgram $(M=132.12)$, Kaliganj $(M=131.08)$, Lamonirhat Sadar $(M=129.71)$, Hatibandha $(M=127.00)$ and Aditmari $(M=124.5)$. The living status of empowered women is $(68.235 \%)$ from single-family. Correlation between education and women empowerment is also significant $(r=0.17)$ at the 0.01 level.
\end{abstract}

Keywords: Women, Empowerment, Elected Women, Local Government

Empowerment is the establishment of self-control over the material, physical, human and intellectual resources of human beings, with which the question of competence is involved. Therefore, women's empowerment refers to a condition in which a woman can be promoted to an independent and dignified position in every aspect of her life. Empowerment can be defined in different ways empowerment means that people (women) outside the decision-making process accept it and allow it. Empowerment is a process that creates power in an individual's own life, society and community. People are empowered where they can take advantage of certain limitations of their education, profession and way of life and by overcoming those limitations they get the opportunities available to them.

\section{Women}

A woman is an adult female human being, as contrasted to men, an adult male, and a girl, a female child. The term woman (irregular plural: women) is used to indicate biological sex distinctions, cultural gender role distinctions, or both (Wikimedia, 2005:1).

Women constitute about half of the total population of the country. Apart from household activities, they are contributing substantially to the national economy. Bangladesh is one of the fast-developing countries to establish a Ministry of Women's Affairs in 1978, three years after the First World Conference on Women in Mexico. The government has already prepared a National Policy for Advancement of Women and made some noteworthy progress in implementing

How to cite this article: Islam M. ASM (2020). Women Empowerment: A Case Study on Elected Women of Local Government in Lalmonirhat District of Bangladesh. Int. J. Soc. Sci., 9(03): 199-204.

Source of Support: None; Conflict of Interest: None (6) 8 
the National Action Plan, prepared in response to the Beijing Platform for Action.

\section{Women's Empowerment}

"Gender equality" and "women's empowerment" were the two broadest issues in development. The term refers to the improvement of women conditions in every sphere of life (Hossain, 2015). However, This indicates the overall development of the backward class of society at almost the same level and in the same situation (Khan and Ara, 2006). Enabling women to organize themselves to increase their self-reliance, ensure their right to selfdetermination to charge resources and help them to take up these challenges and break their subordinate position in society (Keller and Mbwewe, 1991) According to Caroline Moser "Women's ability to increase their selfreliance and inner strength. It is control over important substances and non-material resources the acquisition has been identified as a right to determine life choices and influence change through acquisition". Sen and Grown said, "Women's empowerment is the transformation of structures of subordination, including changes in the law, civil codes, property, inheritance rights, control over women's bodies and labour and the social legal institutions that endorse male's control." The meaning of women empowerment varies by the social and cultural context and with a life cycle (Oppong, 1983; Greenhalgh 1985) and, therefore, there is no consensus regarding empowerment. Recognizing this, we conceptualize women's empowerment by looking at eight aspects of progress: Self-reliance, decision-making ability, small family norms, health care for herself and children, conscious of their rights, gender equity, participation and involvement in the job performance and education.

\section{Women Empowerment and Self-reliance}

Many government and non-government organizations are helping women through self-help initiatives and development. Self-reliance is defined in three ways; Knowing that people can solve a problem for themselves and make sure they have the ability and skill to do something about it and free them from external obstacles (Carter, 2012).

According to Ojameruaye (2004), self-reliant development is defined as that type of development, which relies on their own human and material resources or a do-it-yourself approach.

\section{Women Empowerment and Decision-making Ability}

Women's empowerment refers to the empowerment of women in social, economic and political spheres. Empowerment of women is essential for achieving sustainable development. It is a prerequisite for gender equality and development. Quoting from a UNFPA report, "the state of World Population 1992", the News Letter of Bernard Van Leer Foundation says, that there can be no sustainable development without the advancement of women because women contribute the most to the development of children. Empowerment should start from our own home. The position of women in the family determines the autonomy of women. To verify whether he can make decisions on the use of family resources and the purchase of jewellery, the availability of funds, travel to relatives' homes, or access to healthcare. A study by Hoque and Itohara (2009) reported that microcredit is making some contribution to the economic activities of rural women and family formation in family decision making. He further said that the microcredit program in Bangladesh is increasing gender awareness among women. This study was first considered by considering three important dimensions of women's empowerment that identify five principles where empowerment is achieved: welfare, access equality, awareness-raising, participation and control.

\section{Women Empowerment and Health Care}

Smith et al. (2003) state that improving women's health status can effectively enhance their performance in their socioeconomic responsibilities, including increasing agricultural production by creating more efficient and skilled labourers.

\section{Women Empowerment and Rights}

The CEDAW Convention is instrumental in shaping the legal and policy framework and advancing the international agenda on women's human rights. It has been an inspiration for women in all parts of the world and has been responsible for significant change at the 
country level, as well as in the international sphere. The Constitution of Bangladesh guarantees equal rights (Article 27, 28/1, 28/2,28/3 and 65/3) to enshrined provisions for the equal dignity of all women. (Khan and Ara, 2006).

\section{Women Empowerment and Gender Equality}

Gender equality refers to the equal right of a person to acquire wealth, opportunities and protection in all spheres of life, to participate in economic activities and to make decisions, regardless of their gender. This does not mean, however, that men and women should be treated the same or in the same way.

\section{Women Empowerment and Education}

Education is the key to women empowerment. There is no alternative to women's education for the welfare and progress of the nation. Through education, women are getting more opportunities in the workplace so that they can lead a better life and achieve their goal.

\section{Women Empowerment and Job Involvement}

Women empowerment makes a woman interested in various challenging professions. If women were properly empowered so long as all the work was considered suitable for men, they can do that effortlessly.

\section{Women Empowerment and Small Family Norms}

Various studies have shown that women's empowerment is related to reproductive outcomes, including contraceptive use, and birth rates. Some researchers have suggested that empowerment is a key way through which education affects fertility.

\section{Elected Women}

Bangladesh has a four-tier local government system and in these local government institutions, one-third of the seats are reserved only for women. As such, Bangladesh has about 14,000 women members who elected as a female member or vice-chairman by direct vote of the people. Several other women came to be directly elected. These elected women are in the local government institutions of Bangladeshis called elected women.

\section{Local government}

Local government is an organized social entity with a feeling of oneness. By definition, local government means an intra-sovereign governmental unit within the sovereign state dealing mainly with local affairs, administered by local authorities and subordinate to the state government (Jahan, 1997:92). In political terms, it relates to the management of a particular local territory, it forms the political subdivision of a nation, state or another large political unit. In other words, the local government is an integral part of the political system to govern a country. It then presents a legal concept as a corporate involved in jurisprudence (Muttalib and Khan, 1983:2).

According to the article 59(1) of the Constitution of the People's Republic of Bangladesh, "Local Government in every administrative unit of the Republic shall be entrusted to bodies, composed of persons elected in accordance with law (GOB,1993:43).

\section{Lalmonirhat}

Lalmonirhat is a district located in the northern part of Bangladesh. It is a part of Rangpur division. Lalmonirhat subdivision was established on 1 February 1984 as a district. It is bounded on the north by Kochbihar and Jalpaiguri in West Bengal, on the south by Rangpur, on the east by Kurigram and the west by Nilphamari. Lalmonirhat is a part of the local government of Bangladesh. There are 53 local government institutions in this district. Among them 1 Zila Parishad, 2 Municipalities, 5 Upazila Parishads and 45 Union Parishads. There are more than 150 elected women to represent these local government institutions.

\section{Research Question}

What is the present scenario of women empowerment in local government institutions of Lalmonirhat?

\section{Objective of the Study}

1. To assess and compare women empowerment among women members of union Parishad, Upazila Parishad, municipality and Zila Parishad. 
2. To investigate the most empowered members of local government institutions live in which Upazila.

3. To investigate the living status of empowered women.

4. To assess the relationship between education and women empowerment.

\section{METHODS}

\section{Participants}

This study was conducted on local government institutions of Lalmonirhat district. So, the participants are members of this district local government institution. They are from Union Parishad, Upazila Parishad, Municipality and Zila Parishad. They have been directly elected by vote.

\section{Sample and Sampling Technique}

A total of 85women members participated in this study and they were selected purposively from five different local government institutions. Among them were union Parishad (69), Upazila Parishad (5), the municipality (6) and Zila Parishad (5).

\section{Measuring Instrument}

1. Demographic and Personal Information Questionnaire.

2. Women Empowerment Scale (Bangla Version).

\section{Demographic and Personal Information Questionnaire}

This questionnaire was used to collect personal and demographic information such as name, age etc.

\section{Women Empowerment Scale}

The original version of women empowerment scale (L. Malini and K. Yeshodhara, 2015) was translated into Bangla. It was used to measure women empowerment. There is 50 statement on this scale. The content validity of the scale is ensured as the items were validated at different stages of construction of statements. Chronbach alpha reliability coefficient was calculated and it was found to be 0.8986 and indicates a higher level of reliability in this scale.
In case of positive statements, responses of Agree, Undecided and Disagree option are given a weightage of 3, 2 and 1 respectively. In case of negative statements, the same responses are given a weightage in the reverse order, i.e., 1, 2 and 3 respectively. This being a summated scale the total maximum score on the scale one would get will be $150(50 \times 3)$ and minimum score will be 50 (50x1).

\section{Design}

The present study is on the women empowerment of elected women of local government. This study uses a survey research design to collect data from elected women of local government institutions.

\section{Procedure}

To collect information participants were taken purposively. Before collecting data they were informed about the purpose of the study. Then data was collected using two questionnaires. Participants were asked to write down some personal information and tick the answer which she chose. They were also informed that they would have to answer all the questions. After finishing the answered they were thanked.

\section{RESULTS AND DISCUSSION}

Comparison of women empowerment among union Parishad, Upazila Parishad, municipality and Zila Parishad

Table 1: Mean and SD of Women Empowerment in Different Local Government Institution Members

\begin{tabular}{llll}
\hline Institution & N & Mean & SD \\
\hline Union Parishad & 69 & 128.39 & 7.226 \\
Upazila Parishad & 5 & 129.20 & 6.261 \\
Municipality & 6 & 130.83 & 5.845 \\
Zila Parishad & 5 & 134.40 & 4.159 \\
\hline
\end{tabular}

Source: Calculation from survey data.

Table 1 indicating that the mean difference of women empowerment among union Parishad, Upazila Parishad, municipality and Zila Parishad. Evident showing that means score obtains by Zila Parishad members $(M=$ 134.40) is higher than other institutions members. 


\section{Comparison of women empowerment among five Upazila}

Table 2: Mean and SD of Women Empowerment in Five Upazila

\begin{tabular}{llll}
\hline Name of Upazila & $\mathbf{N}$ & Mean & SD \\
\hline Lalmonirhat Sadar & 14 & 129.71 & 4.858 \\
Aditmari & 19 & 124.05 & 9.880 \\
Kaligang & 24 & 131.08 & 5.970 \\
Hatibandha & 11 & 127.00 & 5.814 \\
Patgram & 17 & 132.12 & 2.870 \\
\hline
\end{tabular}

Source: Calculation from Survey data.

As shown in the above Table 2, the mean difference in Hatibandha Upazila is a little bit higher than the other Upazila. Women empowerment in Patgram Upazila mean scoreis $(M=132.12)$ and standard deviation $(S D$ $=2.870)$.

\section{The living status of empowered women.}

Table 3: Percentage of Living Status of Empowered Women

\begin{tabular}{lll}
\hline Family Status & N & Percentage (\%) \\
\hline Nuclear Family & 3 & 3.529 \\
Single-Family & 58 & 68.235 \\
Joint Family & 24 & 28.235 \\
\hline
\end{tabular}

Source: Calculation from survey data.

Table 3 indicates that $3.529 \%$ of empowered women live in a nuclear family, $69.235 \%$ live in single-family and $28.235 \%$ live in a joint family.

\section{Correlation between education and women empowerment}

Correlation between education and women empowerment is significant $(r=0.17)$ at the .01 level.

The overall purpose of the study was to see the present scenario of women empowerment in local government institutions in Lalmonirhat. For this reason, the study focus on the- (a) to see the comparison of women empowerment of different local government institutions, (b) to investigate in which Upazila is most empowered, (c) to see the living status of empowered women, (d) to investigate the relationship between education and women empowerment. In this present study, the obtained data were analyzed by a different process. The result of the table 1 indicates that the mean score of Zila Parishad women $(M=134.40)$ is more than the other institutions. That mean Zila Parishad women members are most empowered. Among the five Upazila, the women members of patgram Upazila $(M=132.12)$ is most empowered. The present study also showed most of the empowered women came from single-family $(68.235 \%)$. that means they believe in small family norms. One of the most important findings of the study is the relationship between education and empowerment. The result shows a very low correlation between education and women empowerment $(r=0.17)$.

\section{Limitation of the Study}

Of course, this study had several limitations. One of the most serious limitations was that the information was collected in only a district. Also, when some participants new that they will not be benefited from this research directly then they showed their unwillingness to the researcher and didn't cooperate properly. Some limitations like economic, time resource, logistic support and manpower hinder the study.

\section{REFERENCES}

Batliwala, Srilata. 1993. Defining Women's Empowerment: A Conceptual Framework www.genderatwork.org/updir/ Batliwala-empowermentframework.htm

Carter, J. 2012. Reaching self-reliance in development projects. Aid Effectiveness, Community Development, Ethics in development. Available at www.whydev.org/self-reliance-incommunity-development-projects-a-m

DFID, 2000. Poverty Elimination and the Empowerment of Women: Strategies for achieving the international development targets. London: DFID

Everett, Jana. 1991. The Global Empowerment of Women. Summary of the annual conference of the Association for Women in Development, November 17-19, 1989, Washington DC.

Government of Bangladesh (GOB) 1993. The Constitution of the Peoples' Republic of Bangladesh (Amended till October, 1991), Dhaka: Ministry of Law, Justice and Parliamentary Affairs. September.

Hoque, M. and Itohara, Y. 2009. Women empowerment through participation in micro credit programme : a case study from 
Bangladesh, Journal of Social Sciences, Science Publications, Gale.

Jahan, M. 1997. “The Changing Structure of Local Government in Bangladesh: An Overview" in Administration, Communication and Society, 1(1): 91-105.

Jahan, Rounaq. 1995. The Elusive Agenda: Mainstreaming Women in Development. Atlantic Highlands, NJ: Zed Books Ltd.

Kumar, R. 1993. The History of Doing: An Illustrated Account of Movements for Women's Rights and Feminism in India, 1800-1990. New York: Verso.

Keller, B. and Mbwewe, D.C. 1991. Policy and Planning for the Empowerment of Zambia's Women Farmers, Canadian Journal of Development Studies, 12(1): 75-88.

Khan, M.M.R. and Ara, F. 2006. Women, participation and empowerment in local government: Bangladesh Union Parishad perspective, Asian Affairs, 29(1): 73-00.

Khan, M.M.R. and Ara, F. 2006. Women Participation and Empowerment in Local Government: Bangladesh Union Parishad Perspective, Asian Affairs, 29(1): P73-92.

Muttalib, M.A. and Khan, M.A.A. 1983. Theory of Local Government, New Delhi: Sterling Publishers Private Limited.

Ojameruaye, E.O. 2004. Strategies for self-reliant economic development of Urhoboland. [Online]. [Accessed on 02.07.2013]. Available at www.waado.org/geography/ development/ojameruaye_strategies.html

Pitt, M.M., Khandker, S.R. and Cartwright, J. 2006. Empowering Women with Micro Finance: Evidence from Bangladesh, Seminar Paper, The University of Chicago.
Pitt, M. and Khandker, S. 1996. Housholds and intra household impacts of the Grameen Bank and Similar targeted Credit Programmes in Bangaladesh; World Bank Discussion Paper No: 323, Washington D.C.

Results. 1997. The Micro-Credit Summit February 2-4, 1997 Declaration and Plan of Action.

Sen, G. and Caren, G. 1987. Development, Crises, and Alternative Visions: Third World Women's Perspectives. New York: Monthly Review Press.

Smith, L.C., Ramakrishnan, U., Ndiaye, A., Haddad, L. and Martorell, R. 2003. The importance of women's status for child nutrition in developing countries. Research Report 131, International Food Policy Research Institute.

UN Division for the Advancement of Women (UNDAW) Department of Economic and Social Affairs. 2001. Empowerment of Women Throughout the Life-Cycle as a Transformative Strategy for Poverty Eradication. Report of the Expert Group Meeting, 26-29 November. New Delhi, India.

United Nations Children's Fund (UNICEF). 1999. Human rights for children and women: How UNICEF helps make them a reality. Available online at http://www.unicef.org/pubsgen/ humanrights-children/index.html.

Wikimedia. 2005. 22 ${ }^{\text {nd }}$ July .http://en.wikipedia.org/wiki/women, Retrieved on 24.07.2005. 